\title{
Hepatocellular Carcinoma in a Woman with 34 Weeks Gestation and Chronic Hepatitis B
}

\author{
Karina Sato-Espinoza, ${ }^{1}$ Javier Díaz Ferrer, ${ }^{2}$ Yessica Mitzy Jaramillo Ventura ${ }^{3}$ \\ ${ }^{1}$ Médico de planta, Escuela de Medicina, Universidad Peruana de Ciencias Aplicadas. \\ ${ }^{2}$ Médico de planta, Facultad de Medicina, Universidad Nacional Mayor de San Marcos (UNMSM). Hospital Nacional Edgardo Rebagliati Martins. \\ ${ }^{3}$ Médico de planta, Facultad de Medicina, Universidad Nacional Federico Villarreal. \\ Lima, Perú.
}

Acta Gastroenterol Latinoam 2021;51(1):112-115

Received: 13/09/2020 / Accepted: 21/02/2021 / Published online: 22/03/2021 / https://doi.org/10.52787/vxdl1296

\section{Summary}

A 24-year-old pregnant woman arrived at the emergency service at 34 weeks of gestational age with intermittent right upper abdominal pain. An abdominal ultrasound was performed showing signs of hepatopathy with multiple neoformative nodules with mild ascites and fetal biometry confirmed at 34 weeks gestation. During her hospitalization, an emergency caesarean was induced with favorable result in the survival of the mother and the baby.

Keywords. Hepatocellular carcinoma, hepatitis B, non-cirrhotic.

\section{Carcinoma hepatocelular en una mujer con 34 semanas de gestación y hepatitis B crónica}

\section{Resumen}

Una mujer embarazada de 24 años llegó al servicio de urgencias a las 34 semanas de edad gestacional con dolor abdominal superior derecho intermitente. Se realizó una ecografía abdominal que mostró signos de hepatopatía con múltiples nódulos neoformativos con ascitis leve y biometría fetal confirmada a las 34 semanas de gestación. Durante su hospitalización se le indujo una cesárea de urgencia con resultado favorable en la supervivencia de la madre y el bebé.

Palabras claves. Carcinoma hepatocelular, hepatitis $B$, no cirrótica.

\section{Abbreviations}

HCC: Hepatocellular carcinoma.

APGAR: Appearance, pulse, grimace, activity, respiration in the new born.

LDH: Lactate dehydrogenase.

SAAG: Serum ascites albumin gradient.

$P M N$ : Polymorphonuclear.

MN: Mononuclear.

AST-GOT: Aspartate Aminotransferase-Glutamic oxaloacetic transaminase. 
AFP: Alpha fetoprotein.

ALT-GPT: Alanine aminotransferase-glutamic

pyruvic transaminase.

ALP: Alkaline phosphate.

$H B V$ : Hepatitis B virus.

TACE: Trans-arterial chemoembolization.

\section{Introduction}

Hepatocarcinoma is the most common primary liver neoplasm and usually occurs in the context of a cirrhotic liver. However, it is less frequent in patients without cirrhosis. These cases are mainly due to hepatitis B and aflatoxins.

Hepatocarcinoma is a rare condition in pregnant women. The incidence is approximately 1 per 100,000 women, ${ }^{1}$ with a high maternal-fetal mortality rate. The clinical manifestation is variable. It is usually presented with abdominal pain and diagnosed in some cases by physical examination, which is confirmed by an abdominal ultrasound and alpha-fetoprotein values. ${ }^{2}$ Its diagnosis is complex and the survival prognosis for mother and baby is most likely to be low.

\section{Report}

A 24-year-old woman with 34 weeks of gestation, native of Apurimac with residence in Lima, noticed an abdominal mass at the right hypochondrium level a year ago, but she attached no importance to it. There was no weight loss, no early satiety, no fever or other significant manifestation. In addition, there were no prenatal check-ups.

She arrived at the emergency room with 3-day period of illness with intermittent oppressive abdominal pain type $7 / 10$ in the upper quadrant radiating to the lumbar region. During physical examination, a mass is palpated in the right hypochondrium measuring approximately $10 \times 10 \mathrm{~cm}$, which projected to the right flank and iliac fossa; lower limbs showed edema with fovea $++/+++$ and gynecological examination showed no signs of labor. The rest of respiratory, cardiovascular and neurological examinations were normal. An abdominal ultrasound was also perfomed and showed signs of liver disease with multiple neoformative nodules, mild ascites and normal appearance kidneys. In hepatitis B serology laboratory test, the following was found: surface antigen, total anti-core antibodies and antibodies against $\mathrm{E}$ antigen were reactive, but $\operatorname{IgM}$ antinuclear antibodies and antigen $\mathrm{E}$ were non-reactive. In addition, the hepatitis B viral load was $430 \mathrm{UI} / \mathrm{mL}$. Other tests were performed and are detailed in table 1 .
Table 1. Auxiliary Test Results

\begin{tabular}{ll}
\hline Laboratory exams & Results \\
\hline Hepatitis B viral load & $430 \mathrm{Ul} / \mathrm{mL}$ \\
Alpha-fetoprotein (AFP) & $19089.62 \mathrm{ng} / \mathrm{mL}$ \\
CA 19-9 & $13.86 \mathrm{U} / \mathrm{mL}$ \\
Total proteins & $6.15 \mathrm{~g} / \mathrm{dL}$ \\
Albumin & $2.52 \mathrm{~g} / \mathrm{dL}$ \\
Total Bilirubin & $1.72 \mathrm{mg} / \mathrm{dL}$ \\
AST o G0T & $249 \mathrm{U} / \mathrm{L}$ \\
ALT o GPT & $47 \mathrm{U} / \mathrm{L}$ \\
Alkaline phosphatase (FA) & $762 \mathrm{U} / \mathrm{L}$ \\
Lactate dehydrogenase (LDH) & $343 \mathrm{U} / \mathrm{L}$ \\
Hemoglobin & $8.3 \mathrm{~g} / \mathrm{dL}$ \\
Hematocrit & $26.6 \%$ \\
Platelets & $512 \times 109 / \mathrm{L}$ \\
Urea & $12.8 \mathrm{mg} / \mathrm{dL}$ \\
Creatinine & $0.53 \mathrm{mg} / \mathrm{dL}$ \\
Glucose & $36 \mathrm{mg} / \mathrm{dL}$ \\
\hline
\end{tabular}

The abdominal pain intensified and was associated with sporadic dyspnea. Therefore, labor was unsuccessfully induced and ended up in an emergency cesarean. A median incision was made, allowing direct observation and hepatic palpation, obtaining incompatibility with a cirrhotic liver. She delivered a preterm newborn with adequate APGAR, who was given hyper-immune gamma globulin at a dose of $40 \mathrm{UI} / \mathrm{kg}$ and also vaccination against the hepatitis $\mathrm{B}$ virus at birth. After cesarean, paracentesis was performed, obtaining a yellowish ascitic fluid, slightly turbid and without clots. In the biochemical test, we found glucose levels of $12.6 \mathrm{mg} / \mathrm{dL}$, $\mathrm{LDH}$ levels of $107 \mathrm{U} / \mathrm{L}$, protein levels of $1.6 \mathrm{gr}$ and albumin levels of $1 \mathrm{gr} / \mathrm{dL}$. The serum ascites albumin gradient (SAAG) was $\geq 1.1 \mathrm{gr} / \mathrm{dL}$ and the cell count were 93 cells $\mathrm{x} \mathrm{mm} 3$ (7\% PMN, 93\% MN). In the magnetic resonance taken after the cesarean, a severe hepatomegaly was observed with the presence of an extensive heterogeneous, infiltrative and diffuse neoformative lesion. A portal thrombosis was also detected. All these findings were compatible with an advanced multifocal hepatocarcinoma developed in a non-cirrhotic liver (Figure 1 and 2).

The patient was treated with $10 \%$ glucose solution in continuous infusion, in addition to the diet administered. Diuretics were also prescribed with partial response, tramadol on schedule and entecavir $0.5 \mathrm{mg} / \mathrm{dL}$ (this latter administered upon diagnosis of hepatitis $\mathrm{B}$ infection in our Institution). 
Figure 1. In T1, multiple heterogeneous nodular formations are observed that expand the capsule. After contrast administration $(A)$, it shows a tenuous arterial enhancement that persists in the following phases $(\boldsymbol{B})$, probably due to its fibrotic content
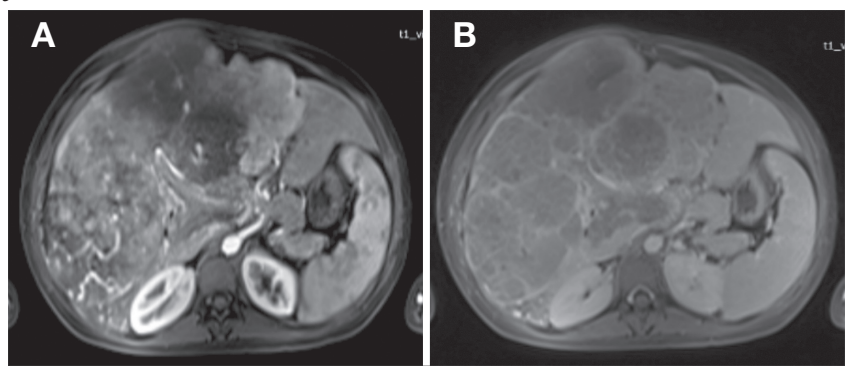

Figure 2. Coronal section shows severe hepatomegaly secondary to the presence of an extensive diffuse infiltrative neoformative lesion and post cesarean section uterine involution
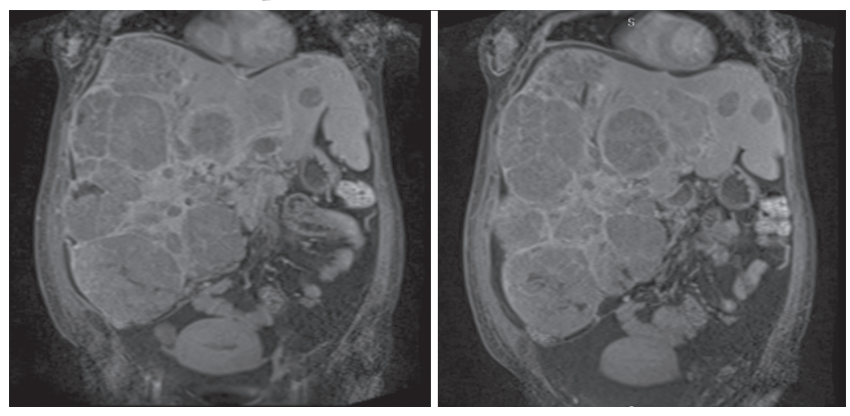

As part of the multidisciplinary workup, the patient was evaluated by the liver surgeon. He reported that, due to the hepatic involvement of the tumor, the portal thrombosis in grade III, according to the YERDEL classification and baseline status of the patient, no type of surgery was feasible. The oncologist dismissed the possibility of systemic chemotherapy due to the high levels of transaminases and alkaline phosphatase associated with severe malnutrition, indicating only palliative management.

A month after discharge, the patient returned to the doctor's office for the check-up and there were no significant changes in terms of laboratory test, but she did present severe consumption and ascites.

\section{Discussion}

Hepatocellular carcinoma (HCC) is the fifth most common cancer and the second leading cause of death worldwide, accounting for $90 \%$ of all primary liver cancers. Its incidence increases with age and it predominates in men. It can be caused mainly by chronic hepatitis C, but also by hepatitis B virus (HBV) and nonalcoholic fatty liver disease. ${ }^{3,4}$

It has been seen that the development of HCC, without previously presenting cirrhosis, is influenced by geographical factors in places such as Asia, Africa and some Latin American countries. In Peru, HCC is the third most frequent cancer in the digestive system. A study conducted in a hospital in Peru ${ }^{4}$ found that the most common etiology associated with HCC was 38.9\% with hepatitis $\mathrm{B}$ virus. In addition, $8.3 \%$ of the patients studied with $\mathrm{HCC}$ were from Apurimac, an incidence related to our patient. On the other hand, a higher incidence was observed at an older age and in male sex, as well as international information. For these reasons, this case is rare, since this diagnosis occurred in a young woman of reproductive age.

In Peru, 15 provinces have been found to have a high prevalence of hepatitis B virus infection (endemic areas). These include Cuzco, Junín, Ayacucho, Apurímac, Abancay and Huánuco, as well as other Amazonian cities. Prevalence varied from 1.3\% in Lima; $9.8 \%$ in Abancay and up to $43 \%$ in the Amazon Basin. High mortality rate was found in the aforementioned provinces and also in younger people with advanced HCC without cirrhosis. ${ }^{5}$ For these reasons, it is vital to reinforce the importance of universal vaccination programs and strengthen existing early diagnosis programs in patients who have risk factors for developing HCC with abdominal ultrasound, tumor markers or hepatic elastography, if applicable. ${ }^{6}$ In addition, if necessary, effective antiviral treatments should be administered to patients with untreated chronic hepatitis $B$ virus infection, despite having an significant epidemiological precedent. ${ }^{7}$

The presentation of HCC in pregnancy is extremely rare, with a prevalence of 1 per $100,000 .{ }^{1}$ It has no specific clinic presentation but nausea, right hypochondrium and upper abdominal pain and vomiting which have been found in several clinical reports. In addition, physical examination found hepatomegaly or palpable mass in the right hypochondrium, for which an abdominal ultrasound scan and alpha-fetoprotein are required. ${ }^{2}$ The diagnosis of HCC in pregnancy is complex and has a poor prognosis for survival. Our patient presented similar clinical symptoms characterized by abdominal pain, nausea and vomiting, lower limb edema and persistent hypoglycemia that occasionally occurs in huge hepatocarcinoma or paraneoplastic as a side effect. HCC has been associated with hypoglycemia as a complication in approximately $3 \%$ to $13 \%$ of the cases and it is possible to find two types. The type A shows that the tumor has grown rapidly, appetite has decreased, weakness is severe and hypoglycemia occurs 
as a terminal event. On the other hand, in the type $\mathrm{B}$, the tumor has a slow growth and the hypoglycemia is present throughout the course of the disease; our patient presented this type of hypoglycemia and had a good response to diet and glucose infusion without managing the underlying disease, which is $\mathrm{HCC}^{8}$

In a study conducted in Korea, ${ }^{9}$ it was observed that the overall survival of pregnant women diagnosed with HCC diagnosis was of 18 months and the prognosis of the babies was: $11 \%$ of intrauterine death, $4,3 \%$ of deaths at the end of pregnancy, most of the reported cases ${ }^{10,11}$ where the evolution for both mother and fetus was torpid, have culminated in death. Nevertheless, our patient, despite of the huge tumor size, managed to survive as did her newborn child. Our patient's diagnosis, even though she was considered non-cirrhotic, could not be corroborated by histology. The treatment that was discouraged for her was TACE, due to the level of portal thrombosis and poor hepatic function. In addition, sorafenib treatment was rejected by the medical oncologists, because of the poor general condition, the patient's malnutrition and the altered hepatic profile characterized by elevation of transaminases and alkaline phosphatase more than 5 times the normal values. For these reasons, palliative treatment was considered.

It should be noted that, although it is true that these treatments have been validated for patients with cirrhosis, they were also proposed for this patient who did not have cirrhosis condition. However, they were not accepted due to her poor general condition. In her second month check-up, the patient was observed with a high consumptive state and ascites that was managed with paracentesis every month, but without significant laboratory changes. On the other hand, the newborn evolved with normal growth and development but exclusively formula fed.

\section{Conclusion}

In some areas of Latin America, due to their weak health systems, the high HBV prevalence shows a serious public health problem. As we present in this case, it is necessary to promote screening for HBV to prevent future complications, especially in patients who were infected vertically, since they may present complications early in life.

\section{Copyright}

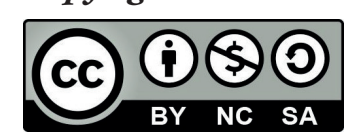

(C) 2021 Acta Gastroenterológica latinoamericana. This is an openaccess article released under the terms of the Creative Commons Attribution (CC BY-NC-
SA 4.0) license, which allows non-commercial use, distribution, and reproduction, provided the original author and source are acknowledged.

Cite this article as: Sato-Espinoza K, Díaz Ferrer J, Jaramillo Ventura YM. Hepatocellular Carcinoma in a Woman with 34 Weeks Gestation and Chronic Hepatitis B. Acta Gastroenterol Latinoam. 2021;51(1):112-5. https://doi. org/10.52787/vxdl1296

\section{References}

1. Lau W, Leung W, Ho S, Lam S, Li C, Johnson P, et al. Hepatocellular carcinoma during pregnancy and its comparison with other pregnancy-associated malignancies. Cancer. 1995;75(11):2669-76.

2. Cobey FC, Salem RR. A review of liver masses in pregnancy and a proposed algorithm for their diagnosis and management. The American journal of surgery. 2004;187(2):181-91.

3. Liver EAftSot. EASL Clinical Practice Guidelines: Management of hepatocellular carcinoma. Journal of hepatology. 2018.

4. Bustíos Sánchez C, Díaz Ferrer J, Román Vargas R, Dávalos Moscol M, Zumaeta Villena E. Características clínico-epidemiológicas del carcinoma hepatocelular y su tratamiento en el departamento del aparato digestivo del HNERM ES-SALUD. Revista de Gastroenterología del Perú. 2009;29(1):17-23.

5. Farfán G, Cabezas C. Mortalidad por enfermedades digestivas y hepatobiliares en el Perú, 1995-2000. Revista de Gastroenterología del Perú. 2002;22:310-23.

6. Diaz-Gonzalez A, Forner A, Rodriguez de Lope C, Varela M. New challenges in clinical research on hepatocellular carcinoma. Rev Esp Enferm Dig. 2015;108:485-93.

7. Liver EAFTSOT. EASL 2017 Clinical Practice Guidelines on the management of hepatitis B virus infection. Journal of hepatology. 2017;67(2):370-98.

8. Marchesini G, Bianchi G. Carbohydrate metabolism in hepatocellular carcinoma: where does the glucose go? Hepatology. 1989;10(2):253-5.

9. Choi KK, Hong YJ, Choi SB, Park YN, Choi JS, Lee WJ, et al. Hepatocellular carcinoma during pregnancy: is hepatocellular carcinoma more aggressive in pregnant patients? Journal of hepatobiliary-pancreatic sciences. 2011;18(3):422-31.

10. Garko SB, David O, Mohammed T, Isah M, Bakari A, Oguntayo A, et al. Hepatocellular carcinoma in pregnancy. Annals of African medicine. 2009;8(4):284.

11. Norouzi A, Tabei MN, Tavassoli S, Besharat S. Hepatocellular Carcinoma in Pregnancy withUnusual Presentations. Middle East journal of digestive diseases. 2012;4(4):228. 